\title{
PENGEMBANGAN DATA WAREHOUSE \\ SEBAGAI SARANA PENUNJANG KEGIATAN AKADEMIK INSTITUT SAINS DAN TEKNOLOGI AL-KAMAL
}

\author{
Darmin \\ Program Studi Teknik Informatika, Fakultas Teknologi Informasi dan Komunikasi Visual \\ Institut Sains dan Teknologi Al-Kamal \\ Jl. Raya Al-Kamal No. 2, Kedoya Selatan, Kebon Jeruk, Jakarta Barat 11520 \\ Email : darmin1112@gmail.com
}

\author{
Article history \\ Received Feb 21, \\ 2020 \\ Revised April 13, \\ 2019 \\ Accepted May 20, \\ 2019 \\ Available online May \\ 31,2020 \\ Keywords \\ Data Warehouse, \\ Four Step Design \\ Methodology, \\ Snowflake Scheme
}

Riwayat Diterima $21 \mathrm{Feb}$ 2020

Revisi 13 April 2020

Disetujui 20 Mei 2020

Terbit 31 Mei 2020

Kata Kunci Data Warehouse, Four Step Design Methodology, Snowflake Schema.

\section{Abstract}

The development of information needs has taken place in all areas, some of which are in business and education. At the Academic Section especially in the field of managing academic data related to college activities by both lecturers and students, Al-Kamal Institute of Science and Technology, then called the Management, currently suffers from obtaining accurate information due to different reports and sources. The existing academic information system condition has not been able to provide the information desired especially about new students', current students' and graduates' profiles which will be used as the basis of decision making analysis. To meet the desired information, an academic Data Warehouse is designed to mainly help the Management to make a decision. Method used in designing the data warehouse is Four Step Design Methodology and the data modeling technique is by using Snowflake Scheme, while the results of data warehouse will be analyzed by using Business Intelligence with OLAP (On-line Analytical Processing). The report will be generated in a dashboard system which will provide graphic information, while the data base used is Microsoft SQL Server 2008. The result of this research is the activation of a database and the related application about the profiles of new students, current students and graduates from any period that is going to be used as a basis in evaluating the performance of each study program by the Management.

\section{Abstrak}

Perkembangan kebutuhan informasi yang meliputi seluruh bidang, baik di bidang bisnis, pendidikan, dan lain-lain. Dalam bidang pendidikan di Institut Sains dan Teknologi Al-Kamal terutama dalam mengelola data-data akademik yang berhubungan dengan aktifitas kegiatan perkuliahan baik dosen maupun mahasiswa, saat ini pihak manajemen mengalami kesulitan mendapatkan informasi yang akurat disebabkan data diperoleh dari laporan dan sumber data yang berbeda. Kondisi sistem informasi akademik yang ada belum mampu menghasilkan informasi yang diinginkan pihak manajemen mengenai profil mahasiswa baru, profil mahasiswa dan profil lulusan, hasil informasi dari profil tersebut akan digunakan sebagai landasan analisa dalam pengambilan keputusan. Untuk memenuhi kebutuhan, maka dirancang sebuah data warehouse akademik yang mempunyai peranan penting dalam membantu manajemen dalam penganbilan keputusan. Metode yang digunakan dalam perancangan data warehouse adalah Four Step Design Methodology, teknik untuk memodelkan data menggunakan snowflake schema, hasil dari data warehouse akan dianalisis menggunakan Business Intelligence dengan OLAP (On-Line Analytical Processing). Bentuk laporan yang dihasilkan dalam sebuah dashboard sistem yang menghasilkan laporan dalam bentuk grafik, data base yang digunakan adalah Microsoft SQL Server 2008. Hasil dari penelitian ini terciptanya sebuah pangkalan data dan aplikasinya yang dapat menghasilkan informasi tentang profil mahasiswa baru, profil mahasiswa dan profil lulusan dari periode ke periode yang akan digunakan sebagai dasar dalam mengevaluasi kinerja setiap program studi oleh manajemen. 


\section{PENDAHULUAN}

Perkembangan kebutuhan informasi yang meliputi seluruh bidang, baik di bidang bisnis, pendidikan, dan lain-lain. Dalam bidang pendidikan di Institut Sains dan Teknologi AlKamal terutama dalam mengelola data-data akademik pihak manajemen mengalami kesulitan mendapatkan informasi tentang profil mahasiswa baru, profil mahasiswa dan profil lulusan yang akan digunakan sebagai dasar analisa dalam pengambilan keputusan disebabkan laporan didapat dari sumber data yang berbeda. Untuk mengatasi masalah tersebut perlu dibangun data warehouse yang mampu mengolah data dari berbagai macam sumber data sehingga mampu memberikan informasi yang dibutuhkan manajemen. Metode yang digunakan untuk merancang data warehouse adalah Four Step Design Methodology, teknik memodelkan data menggunakan snowflake schema, hasil rancangan akan dianalisis menggunakan tools Microsoft SQL Server 2008.

\section{TINJAUAN PUSTAKA}

Menurut Han, J. and Kamber, M. 2006, Data Warehouse merupakan penyimpanan data yang berorientasi objek, terintegrasi, mempunyai variant waktu, dan menyimpan data dalam bentuk nonvolatile sebagai pendukung manajemen dalam proses pengambilan keputusan.

Menurut Kimball, Ralph and Ross, Margy. (2002), untuk merancang data warehouse dengan Four Step Design Methodology yaitu menekankan sumber data yang ada. Entity sumber data yang ada dianalisis untuk memberikan titik awal dalam mendesain suatu data warehouse.

Menurut Michael V. Mannino. 2012, desain model data warehouse dibentuk dari data multi dimensional yang membentuk OLAP, model ini dibuat berdasarkan sudut pandang si pengguna. Hal ini diantaranya telah dilakukan Joko Prasetiana, 2013, untuk memanfaatkan data warehouse yang menghasilkan informasi strategis tentang penerimaan mahasiswa baru untuk menunjang kegiatan promosi di Institut Sains dan Teknologi Al-Kamal. Data warehouse merupakan sejumlah besar data yang dikumpulkan, yang kemudian diolah melalui proses pembersihan (cleansing), ekstraksi (extraction), dan transformasi (transform), menjadi sekumpulan data yang dapat menyediakan informasi strategis dan mendukung usaha pengambilan keputusan.

\section{Karakteristik Data Warehouse}

Karakteristik data yang dimiliki data warehouse menurut Inmon, W.H. 2002, adalah

a. Subject-oriented : Data warehouse didesain untuk menganalisa data berdasarkan subject oriented tertentu dalam organiasi (seperti customers, products, dan sales, bukan pada proses atau fungsi aplikasi tertentu (customer invoicing, stock control, dan product sales).

b. Integrated : Data warehouse dapat menyimpan data-data yang berasal dari sumber sumber yang terpisah ke dalam suatu format yang konsisten dan saling terintegrasi satu dengan lainnya. Syarat integrasi sumber data dipenuhi dengan berbagai cara, seperti konsisten dalam penambahan variabel. Konsisten dalam ukuran variabel, konsisten dalam struktur pengkodean dan konsisten dalam atribut fisik dari data.

c. Time - Variant : Sistem operasional terdapat data yang mempunyai nilai sekarang sedangkan dalam data warehouse terdapat data yang tidak hanya data sekarang tetapi juga data history yang akan digunakan untuk menganalisa serta membantu pengambilan keputusan. Waktu adalah dimensi penting yang harus didukung oleh data warehouse

d. Non - Volatile : Data dalam database operasional akan di pindahkan secara periodik ke dalam data warehouse. Apakah pemindahan data perhari, perminggu, perbulan atau sesuai dengan jadwal yang di tentukan.

\section{Fungsi Data Warehouse}

Data Warehouse mempunyai kegunaan sebagai berikut:

a. Pembuatan laporan

Proses pembuatan laporan melibatkan query sumber data dengan model logika yang berbeda-beda untuk menghasilkan sebuah laporan yang bersifat human-readable, contohnya, pengguna komputer yang melakukan query pada database bagian human resources dan capital improvements untuk menunjukkan tentang bagaimana efisiensi ruang yang digunakan di seluruh perusahahan, Moeller, Robert R. 2007. 
b. OLAP (Online Analitycal Processing)

OLAP adalah sebuah konsep data multidimensional dengan mengkonseptualisasi data transaksional perusahaan, Scheps, Swain. 2008. Bukan hanya mengagregasi dan meringkas data, OLAP memberikan kemampuan pada sistem Business Intelligence untuk melihat data dengan cara baru.

\section{Arsitektur Data Warehouse}

Arsitektur adalah sekumpulan peraturan atau struktur yang menyediakan kerangka kerja untuk merancang sistem atau produk secara keseluruhan Poe, Vidette. 1996. Arsitektur data warehouse memungkinkan pemakai untuk menggabungkan data dari berbagai sumber yang berbeda, serta menjadikannya sebuah basis data.

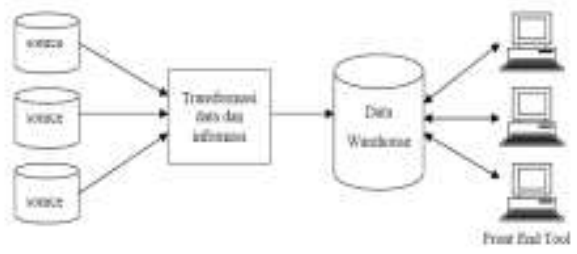

\section{Gambar 1 : Arsitektur Data Warehouse}

Arsitektur data menyediakan kerangka dengan mengidentifikasi dan memahami bagaimana data akan dipindahkan melalui sistem dan digunakan dalam perusahaan. Arsitektur data untuk data warehouse mempunyai komponen utama yaitu database yang hanya dapat dibaca atau read only database.

Karakteristik arsitektur data warehouse menurut Poe, Vidette. 1996 yaitu:

a. Data diambil dari sistem asal (sistem informasi yang ada), database dan file.

b. Data dari sistem asal diintegrasikan dan ditransformasikan sebelum disimpan ke dalam Database Management System (DBMS) seperti Oracle, Ms SQL Server, MySql, Sybase dan masih banyak yang lainnya.

c. Data warehouse adalah jenis databases readonly yang diciptakan untuk mengambil keputusan.

d. User mengakses data warehouse melalui fron - end tool atau aplikasi.

\section{Model Dimensional}

Model Dimensional adalah teknik untuk membuat konseptualisasi dan visualisasi data model sebagai satu set langkah yang dijelaskan oleh aspek-asek umum dari bisnis. Model dimensional memiliki beberapa konsep dasar menurut Ballard, C., et all, 2008. yaitu :

a. Facts (Fakta) : Fakta adalah sekumpulan data yang berhubungan dengan detail data. Dalam data warehouse diterjemahkan semua data yang ada pada transaksi di simpan.

b. Dimensions (Dimensi) : Dimensi adalah serangkain data pada tampilan yang memiliki tipe yang sama dalam dimensional model, setiap titik data dalam tabel fakta dikaitkan dengan satu dan hanya satu anggota dari masing-masing dimensi.

c. Measures/Variables (Ukuran) : Measures / Variables adalah atribut numerik dari suatu tabel fakta yang mewakili kinerja terhadap dimensi yang ada.

\section{Pemodelan Data Warehouse}

Menurut Michael V. Mannino. 2012, Desain model data warehouse dibentuk dari data multi dimensional yang membentuk OLAP. Model ini dibuat berdasar sudut pandang si pengguna. Ada tiga skema untuk pemodelan data warehouse yaitu:

a. Star Schema : Pada Star Schema tabel dimensi tidak memiliki sub dimensi, dimana skema ini memiliki satu tabel fakta dan beberapa tabel dimensi yang mengelilinginya, semua tabel dimensi berpusat pada tabel fact seperti bentuk bintang.

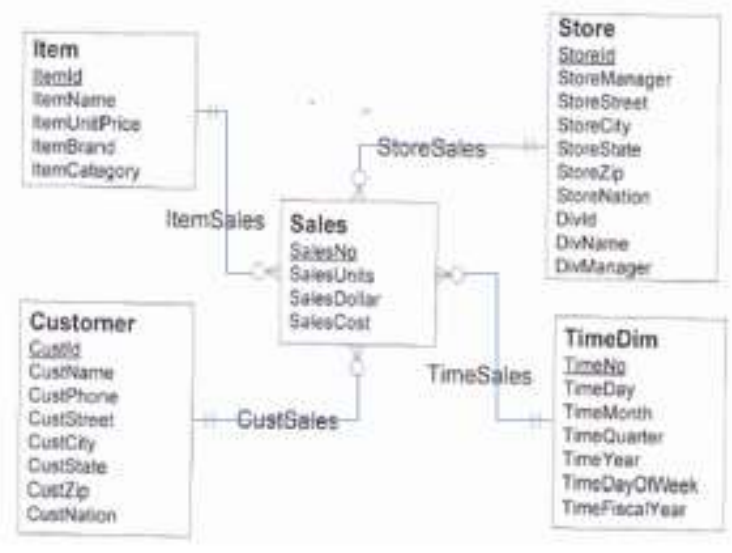

Gambar 2: Star schema

b. Snowflake Schema : Merupakan variasi dari Star schema dimana dimension table-nya tidak mengandung data yang di denormalisasi. Snowflake Schema

JIKA $\mid 120$ 
memungkinkan dimension untuk mempunyai dimension

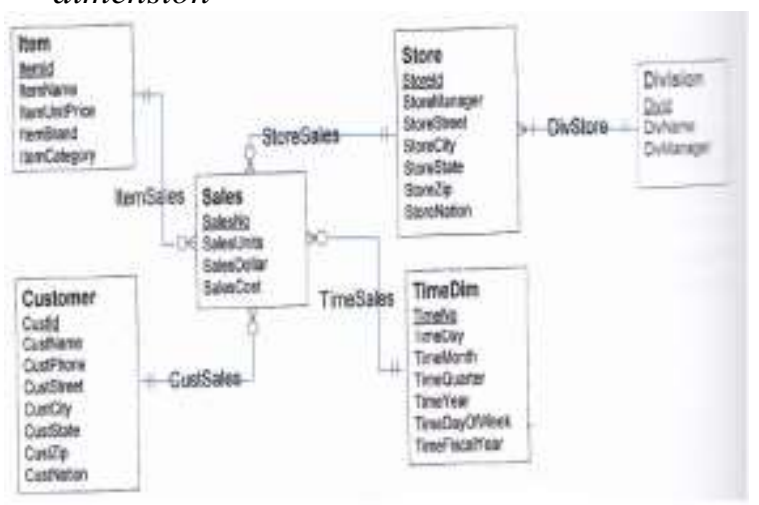

Gambar 3 : Snowflake Schema

c. Fact Constellation : Sebuah skema Fact Constellation terdiri dari satu set skema bintang dengan hirarki terkait dengan tabel fakta.

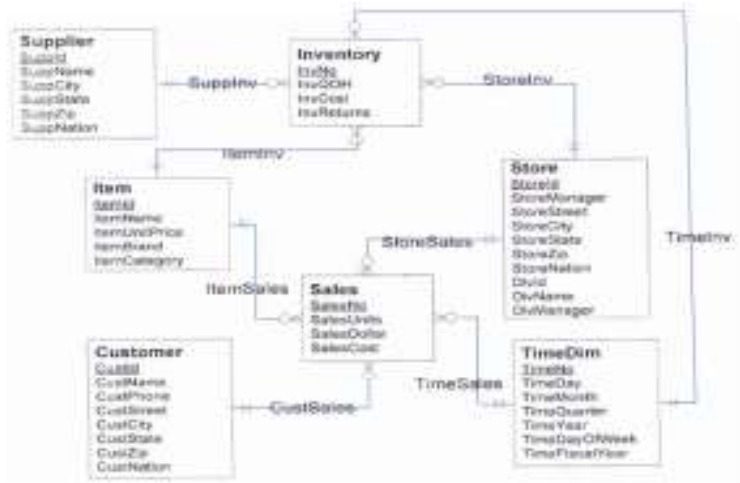

Gambar 4 : Fact Constellation schema

\section{Business Intelligence (BI)}

Digunakan untuk aplikasi dan teknologi dalam mengumpulkan, menyimpan, menganalisa, dan menyediakan akses pada data sehingga dapat membantu pengguna dari kalangan perusahaan atau organisasi untuk mengambil keputusan dengan lebih baik dan tepat, Brannon and Nadia, 2010. Salah satu alat yang mendukung pengembangan dan administrasi aplikasi BI adalah SQL Server 2008 Integration Services (SSIS) dimana alat ini digunakan untuk melakukan proses pengumpulan data dari berbagai sumber (Extract), membersihkannya (Transform), dan kemudian menyimpannya di sistem lain (Load).

\section{METODOLOGI PENELITIAN}

Menurut Kimball, et all. 2002, dalam membangun sebuah data warehouse dengan Four Step Design Methodology yaitu dengan menekankan sumber data yang ada.

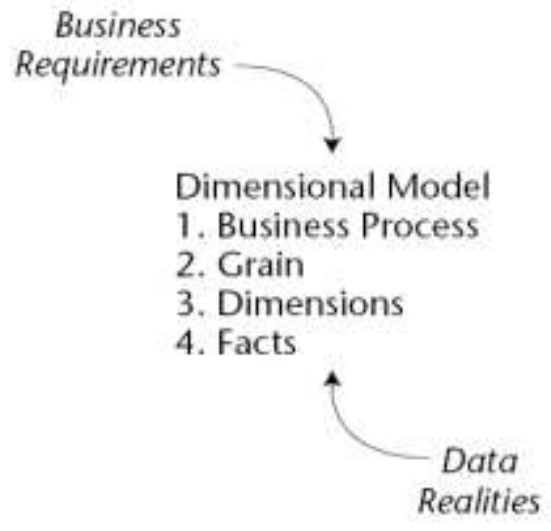

Gambar 5 : Four Step Design Methodology

Ada empat tahap untuk mendesain sebuah Data Warehouse yaitu:

a. Select the business process to model: Melakukan pemilihan proses bisnis yang menjadi fokus user yang mengidentifikasikan letak data berada.

b. Declare the grain of the business process : Melakukan pembentukan tabel fakta sebagai bagian dari proses bisnis.

c. Choose the dimensions : Menentukan dimensi atau sudut pandang yang mungkin dalam mendeskripsikan fakta.

d. Identify the numeric facts : Menentukan hal yang akan dihitung atau diukur.

\section{HASIL DAN PEMBAHASAN}

Pemilihan proses bisnis dilakukan berdasarkan sumber data yang diperoleh antara lain data dari Biro Marketing dan Humas yang menangani proses penerimaan mahasiswa baru, Biro Akademik yang menangani proses kegiatan perkuliahan dan Bagian Alumni yang menangani proses data lulusan.

Mendeklarasikan Grain merupakan data dari calon fakta yang akan dianalisis yaitu dengan melakukan pemilihan grain, maka dapat diputuskan hal-hal apa saja yang akan direpresentasikan pada record tabel fakta. Grain-grain yang terdapat dalam perancangan data warehouse akademik terdiri dari :

a. Proses Profil Mahasiswa Baru : Data yang akan dianalisa adalah jumlah mahasiswa yang mendaftar setiap program studi, jumlah pendaftar mahasiswa baru dari asal sekolah SMU/SMK dan mahasiswa baru pindahan atau alih studi asal perguruan tinggi lain, 
sedangkan proses sumber informasi calon mahasiswa yang diterima yaitu ketika calon mahasiswa mencari informasi yang berasal dari beberapa media promosi antara lain : brosur, karyawan, mahasiswa, sekolah, spanduk, surat dan web ista.ac.id.

b. Proses Profil Mahasiswa : Data yang akan dianalisa adalah jumlah mahasiswa dengan status aktif, Jumlah mahasiswa dengan status non aktif, Jumlah mahahasiswa dengan status cuti dan Jumlah mahasiswa dengan status keluar.

c. Proses Profil Lulusan : Data yang akan dianalisa adalah lulusan setiap program studi berdasarkan Indeks Prestasi Kumulatif (IPK) tertinggi, rata-rata dan terendah.

Pemilihan Dimensi disesuaikan dengan grain yang ada yaitu,

Tabel 1 : Pemilihan Dimensi

\begin{tabular}{|c|c|c|c|c|c|c|c|c|}
\hline $\begin{array}{l}\text { Penyesuain } \\
\text { Dimensi } \\
\text { dan } \\
\text { Grain }\end{array}$ & Waktu & Mahasiswa & Fakultas & Prodi & $\begin{array}{l}\text { Status } \\
\text { Mahasiswa }\end{array}$ & $\begin{array}{l}\text { Waktu } \\
\text { Tahun } \\
\text { akademik }\end{array}$ & Informasi & $\begin{array}{l}\text { Calon } \\
\text { Mahasiswa }\end{array}$ \\
\hline $\begin{array}{l}\text { Jumlah } \\
\text { mahasiwa } \\
\text { aktif per } \\
\text { program } \\
\text { studi } \\
\end{array}$ & $X$ & $\mathrm{X}$ & $\mathrm{X}$ & $X$ & & & & \\
\hline $\begin{array}{l}\text { Jumlah } \\
\text { mahaiswa } \\
\text { non aktif } \\
\text { per } \\
\text { program } \\
\text { studi } \\
\end{array}$ & $\mathrm{X}$ & $\mathrm{X}$ & $\mathrm{X}$ & $\mathrm{X}$ & & & & \\
\hline $\begin{array}{l}\text { Jumlah } \\
\text { mahasiswa } \\
\text { cuti } \\
\text { perprogram } \\
\text { studi } \\
\end{array}$ & $\mathrm{X}$ & $X$ & $X$ & $X$ & & & & \\
\hline $\begin{array}{l}\text { Jumlah } \\
\text { mahasiswa } \\
\text { keluar } \\
\text { perprogram } \\
\text { studi } \\
\end{array}$ & $X$ & $X$ & $\mathrm{X}$ & $\mathrm{X}$ & & & & \\
\hline $\begin{array}{l}\text { Jumlah } \\
\text { mahasiswa } \\
\text { baru per } \\
\text { program } \\
\text { studi } \\
\text { pertahun } \\
\text { akademik } \\
\end{array}$ & & & $X$ & $X$ & $\mathrm{X}$ & & & $\mathrm{X}$ \\
\hline $\begin{array}{l}\text { Jumlah } \\
\text { informasi } \\
\text { yang } \\
\text { diterima } \\
\text { ketika } \\
\text { calon } \\
\text { mahasiswa }\end{array}$ & $\mathrm{X}$ & & $\mathrm{X}$ & $\mathrm{X}$ & & & $\mathrm{X}$ & $\mathrm{X}$ \\
\hline
\end{tabular}




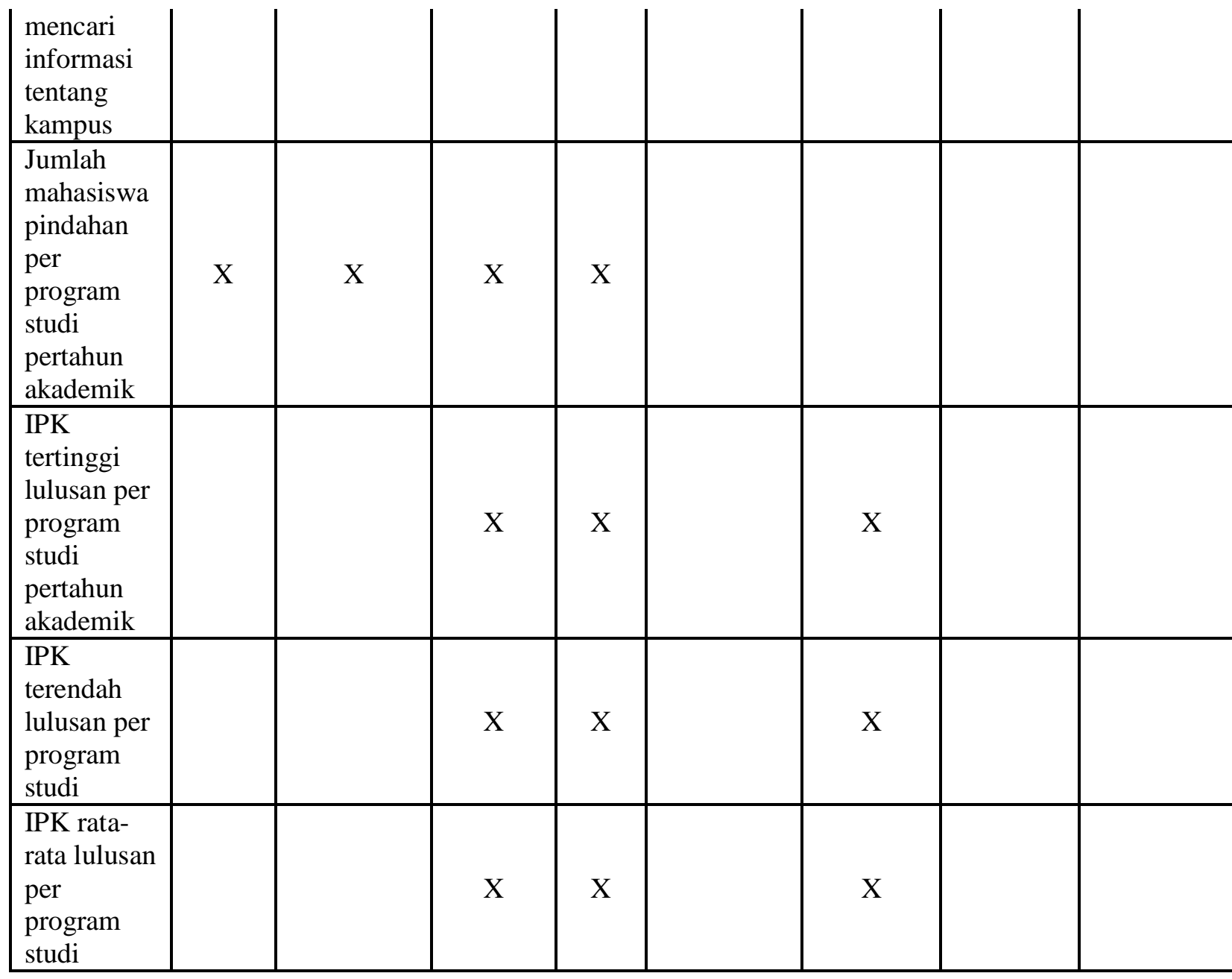

Mengidentifikasi Fakta dilakukan berdasarkan pemilihan fakta-fakta yang sesuai dengan kebutuhan. Setiap fakta yang terbentuk, terdiri dari atribut dimensi dan data measure. Fakta yang terbentuk dari perancangan data warehouse adalah :

a. Proses profil mahasiswa baru terdiri dari beberapa tabel fakta yang terbentuk adalah tabel Factcalonmahasiswabaru yang terdiri dari beberapa atribut pendukung yaitu : noseleksi, kdprodi, statusasal, idwaktu. Proses Profil Mahasiswa baru status asal dari Diploma / alih kredit, tabel fakta yang terbentuk adalah tabel Factcalonmahasiswapin yang terdiri dari beberapa atribut pendukung yaitu: noseleksi, kdprodi, statusasal, idwaktu. Proses Profil Mahasiswa Baru yang berasal dari beberapa asal Informasi yang berkaitan dengan pendaftaran, tabel fakta yang terbentuk adalah tabel Factcalonmahasiswainfo yang terdiri dari beberapa atribut pendukung yaitu : noseleksi, kdprodi, kdinfo, idwaktu.

b. Profil Mahasiswa terdiri dari beberapa tabel fakta yang terbentuk yaitu : mahasiswa status aktif adalah tabel Factmahasiswaaktip yang terdiri dari beberapa atribut pendukung yaitu: nimhsmsmhs, kdprodi, idwaktu. Mahasiswa status non aktif tabel fakta yang terbentuk adalah tabel Factmahasiswanonaktip yang terdiri dari beberapa atribut pendukung meliputi : nimhsmsmhs, kdprodi, idwaktu. Mahasiswa status cuti tabel fakta yang terbentuk adalah tabel factmahasiswacuti yang terdiri dari beberapa atribut pendukung meliputi: nimhsmsmhs, kdprodi, idwaktu. Mahasiswa status keluar tabel fakta yang terbentuk adalah tabel factmahasiswakeluar yang terdiri dari beberapa atribut pendukung meliputi: nimhsmsmhs, kdprodi, idwaktu.

c. Profil Lulusan terdiri dari beberapa tabel 
fakta yang terbentuk, yaitu : lulusan dengan IPK tertinggi adalah tabel factipktertinggi yang terdiri dari beberapa atribut pendukung meliputi: kdprodi, idwaktu, ipktertinggi. Lulusan dengan IPK rata-rata, tabel fakta yang terbentuk adalah tabel factipkrata yang terdiri dari beberapa atribut pendukung meliputi : kdprodi, idwaktu, ipkratarata. Lulusan dengan IPK terendah, tabel fakta yang terbentuk adalah tabel factipkterendah yang terdiri dari beberapa atribut pendukung meliputi : kdprodi, idwaktu, ipkterendah.

Setelah beberapa kebutuhan berhasil dirumuskan maka selanjutnya adalah mendeskripsikan sistem yang akan dibangun dengan merancang arsitektur fisik data warehouse,

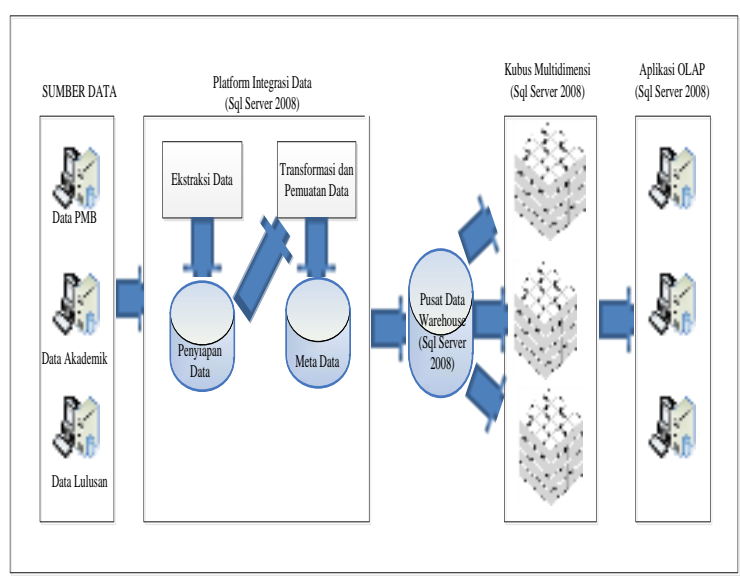

Gambar 6: Rancangan Arsitektur Fisik Data

\section{Warehouse}

Di dalam perancangan data warehouse ini, user mengakses data warehouse melalui server aplikasi. Data warehouse dan server aplikasi direncanakan berada pada mesin yang sama.

Data yang akan digunakan untuk analisis didapat dari data excel PMB dan data excel lulusan dan database operasional akademik. Pada data tersebut dilakukan proses ekstraksi, pembersihan, transformasi dan pemuatan data untuk dipindahkan ke dalam database data warehouse. Data yang telah dipindahkan ke dalam basis data data warehouse dirancang beberapa kubus yang akan digunakan untuk analisis data berdasarkan kubus-kubus yang terbentuk. Manajemen dapat melakukan analisis terhadap informasi dari berbagai dimensi yang berbeda-beda. Untuk memudahkan melakukan analisis dibangun sebuah aplikasi OLAP dengan menggunakan Tools Microsoft SQL Server 2008.

Data mentah dalam bentuk Microsoft Excel dan database siakad akademik diekstrak, diubah bentuknya ke dalam format SQL. Setelah data mengalami proses transformasi selanjutnya dilanjutkan dengan pembersihan data yang memakan waktu cukup lama apabila jumlah record yang sangat banyak. Pembersihan data meliputi penghilangan redundansi data, membersikan data yang tidak konsisten, misalnya menyamakan nama atribut, dan kemudian membuat hubungan antara semua tabel. Data yang diambil adalah data calon mahasiswa untuk beberapa angkatan, data mahasiswa aktif, non aktif, cuti dan keluar setiap semester dan data lulusan per tahun.

Berikut ini adalah beberapa tabel fakta dan tabel dimensi yang telah bersih, yang telah dapat digunakan untuk merancang skema data warehouse setelah melewati proses extract, transformation dan loading (ETL). Terdapat beberapa tabel dimensi dan satu tabel sub dimensi yang terhubung dengan satu tabel fakta, sebagai berikut:

\begin{tabular}{l|l|c|}
\multicolumn{1}{c|}{ Column Name } & \multicolumn{1}{c}{ Data Type } & Allow Nulls \\
\hline kdprodi & nvarchar(MAX) & $\nabla$ \\
\hline kdfak & nvarchar(MAX) & $\nabla$ \\
\hline nmprodi & nvarchar(MAX) & $\nabla$ \\
\hline aliasprodi & nvarchar(MAX) & $\nabla$ \\
\hline nmketuaprodi & nvarchar(MAX) & $\square$ \\
\hline
\end{tabular}

Gambar 7 : Desain Tabel Dimensi Prodi

\begin{tabular}{|l|l|l|}
\multicolumn{1}{|c|}{ Column Name } & \multicolumn{1}{c}{ Data Type } & Allow Nulls \\
\hline kdfakl & nvarchar(MAX) & $\nabla$ \\
\hline nmfak & nvarchar(MAX) & $\nabla$ \\
\hline nmdekanfak & nvarchar(MAX) & $\square$ \\
\hline
\end{tabular}

Gambar 8 : Desain Tabel Dimensi Fakultas

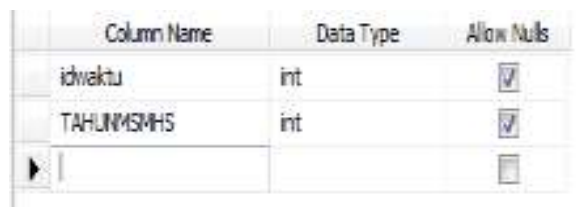


Gambar 9: Desain Tabel Dimensi Waktu

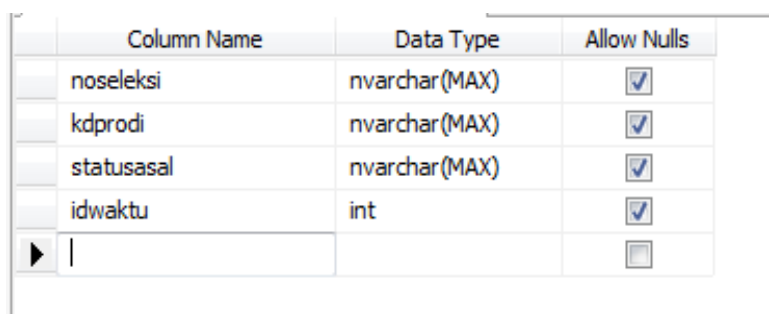

Gambar 10 : Desain Tabel Fakta Mahasiswa Baru

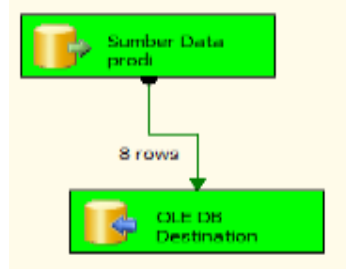

Gambar 11: Proses ETL Dimensi Prodi

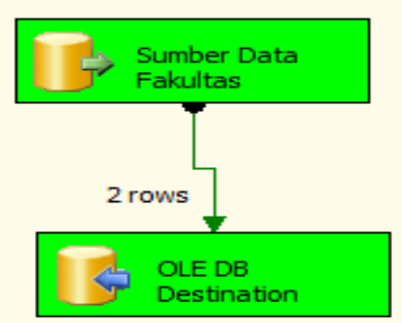

Gambar 12: Proses ETL Dimensi Fakultas

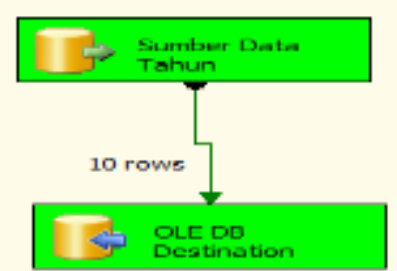

Gambar 13: Proses ETL Dimensi Waktu

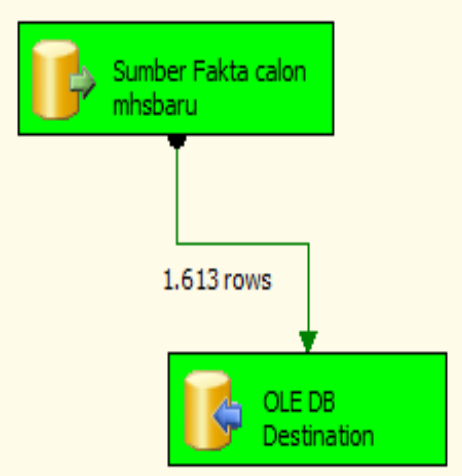

Gambar 14: Proses ETL Fakta Calon

\section{Mahasiswa Baru}

Hasil desain tabel dimensi, tabel fakta dan proses ETL tidak dapat dituliskan semuanya secara jelas, dimana desain tabel dimensi, tabel fakta dan proses ETL memiliki kemiripan antar setiap anggotanya, dan setiap anggota memiliki perbedaaan dengan anggota lainnya.

Setelah proses empat tahap desain database untuk membangun data warehouse akademik, selanjutnya akan menghasilkan skema dalam bentuk Snowflake schema yang terdiri atas satu tabel fakta dan beberapa tabel dimensi dan sub dimensi yang sudah baik dan bersih dalam tampilannya dan dapat ditelusuri, selanjutnya informasi apa saja yang dapat digali dengan implementasi data warehouse menggunakan SQL Server Business Intelligence Development Studio. Sebuah project dalam bentuk analysis services project dibuat menjadi kubus, dengan terlebih dahulu membuat solution explore, menentukan server name, mengambil database untuk data sources, memilih tabel yang sesuai, membuat cubes dan dimensions. 


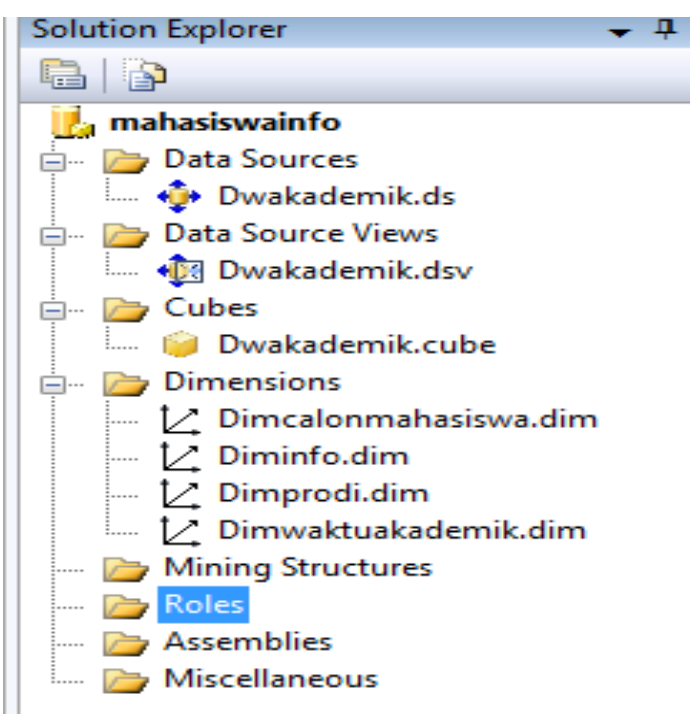

Gambar 15 : Solution Explorer kubus

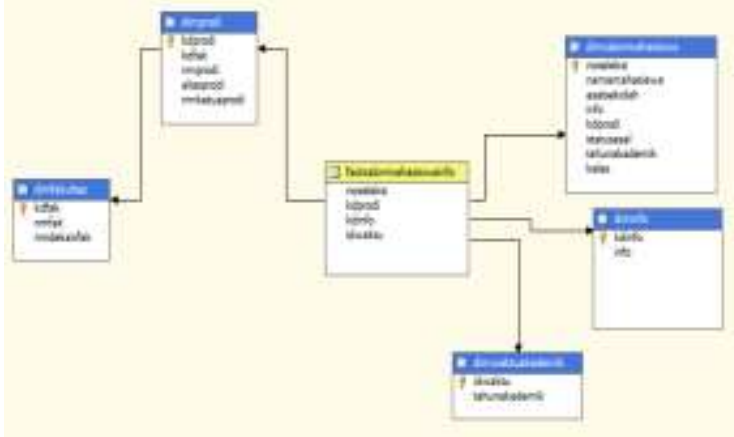

Gambar 16 : Kubus Snowflake schema

Dari hasil kubus tersebut menghasilkan laporan yang terbentuk dari OLAP menggunakan Microsoft SQL Server Analysis Service, berikut ini adalah bentuk laporan yang dihasilkan dari proses OLAP.

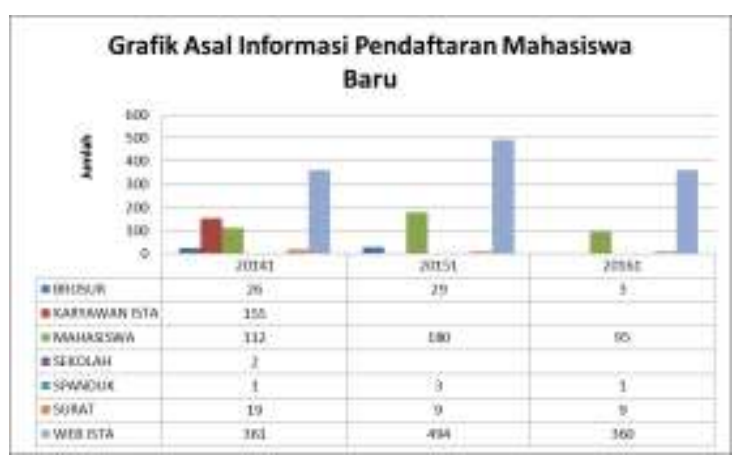

Gambar 17: Laporan Grafik Sumber Informasi

Dari grafik sumber informasi yang didapat adalah jumlah sumber informasi yang diperoleh calon mahasiswa dan dapat mengambil kesimpulan untuk menentukan media promosi mana yang paling cocok dalam rangka mempromosikan kepada calon mahasiswa sehingga dapat meminimalkan anggaran biaya

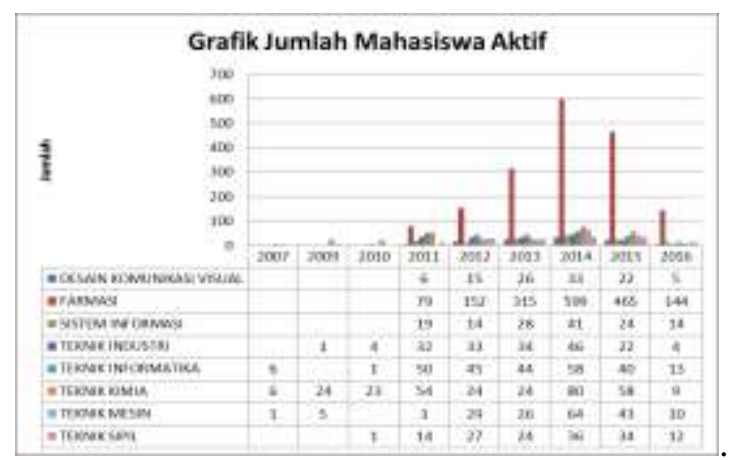

Gambar 18: Laporan Grafik Jumlah

\section{Mahasiswa Aktif}

Dari grafik tersebut informasi yang didapat adalah jumlah mahasiswa aktif setiap program studi setiap tahun akademik dan dapat mengambil kesimpulan bahwa dapat mengetahui jumlah mahasiswa yang berstatus aktif.

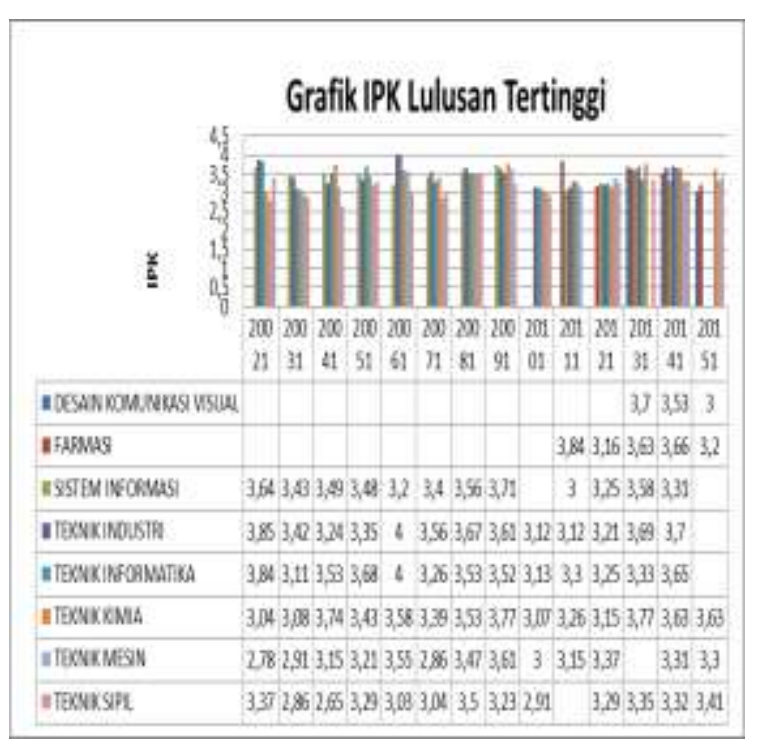

Gambar 19: Laporan Grafik IPK Lulusan

\section{Tertinggi}

Dari grafik tersebut informasi yang didapat adalah IPK lulusan tertinggi setiap program studi dan dapat mengambil kesimpulan bahwa 
dapat mengetahui IPK lulusan tertinggi dari setiap program studi.

Bentuk laporan yang dihasilkan dari proses OLAP yang menghasilkan laporan grafik juga tidak dapat dituliskan semuanya secara jelas, karena hasil dalam bentuk laporan yang berjumlah cukup banyak, dimana setiap laporan memiliki kemiripan yang ditampilkan.

\section{KESIMPULAN DAN SARAN}

Kesimpulan yang dapat ditarik dari analisis dan pembahasan adalah sebagai berikut:

a. Model data warehouse yang dibangun dan disesuaikan dengan kebutuhan stakeholder dapat memberikan informasi strategis untuk menunjang kegiatan akademik serta dapat dijadikan sebagai acuan para pengambil keputusan tingkat fakultas untuk mendukung proses evaluasi dan perencanaan dibidang akademik.

b. Dengan bantuan presentasi data dari data warehouse dan business intellgent, berdampak pada efektifitas pembuatan laporan dan penghematan biaya operasional sehari-hari karena laporan yang sebelumnya harus dicetak, kini dapat diminimalkan.

c. Data Warehouse yang dihasilkan dapat diimplementasikan dengan sebuah aplikasi yang mendukung proses OLAP untuk menampilkan laporan yang diperlukan.

Dari hasil penelitian, implikasi dan kesimpulan, selanjutnya peneliti dapat memberikan beberapa saran yang relevan dengan hasil penelitian, antara lain :

a. Hendaknya dilakukan proses validasi dan standarisasi terhadap masukan data pada beberapa sistem yang digunakan di ISTA, sehingga dapat menghindari dari permasalahan data yang tidak konsisten.

b. Pada pengembangan selanjutnya dapat dibuat data mining untuk memprediksi serta mengetahui pola karakteristik mahasiswa mulai dari proses pendaftaran, menjadi mahasiswa, hingga mahasiswa lulus.

\section{REFRENSI}

Ballard, C., Herreman, D., Schau, D., Bell, R., Kim, E., \& Valencic, A. 2008. "Data Modeling Techniques for Data Warehousing”. IBM .

Brannon and Nadia, 2010. "Business Intelligence and E-Discovery". July 2010.Intellectual Property \& Technology Law Journal Vol. 22 No. 7 Page 1-5

Han, J. and Kamber, M. 2006. "Data Mining Concepts and Techniques" Second Edition. Morgan Kauffman, San Fransisco.

Inmon, W.H. 2002. Building the Data Warehouse,edisi-3. Wiley Computer Publishing.

Joko Prasetiana, 2013. "Perancangan Data Warehouse Penerimaan Mahasiswa Baru Untuk Menunjang Kegiatan Promosi”. Tesis, M.Kom, Sekolah Tinggi Manajemen Informatika dan Komputer Nusa Mandiri, Jakarta.

Kimball, Ralph and Ross, Margy. 2002. "The Data Warehouse Toolkit" Second Edition. Canada. John Wiley and Sons, Inc.

Michael V. Mannino. 2012. "Database Design, Application Development, and Administration", $5^{\text {th }}$ Edition, University of Colorado, Denver.

Moeller, Robert R. 2007. COSO Enterprise Risk Management: "Understanding the New Integrated ERM Framework". John Wiley \& Sons.

Poe, Vidette. 1996. "Building a Data Warehousing for Decision Support". New Jersey: Prentice Hall PTR.

Scheps, Swain. 2008. "Bussiness Intelligence for Dummies". $1^{\text {th }}$ Edition. Indiana : Wiley. 